\title{
Scientific Investigation of Metal Threads from Medieval Gold Brocaded Velvets by Modern Microanalytical Techniques
}

\author{
ZIZI ILEANA BALTA ${ }^{1 *}$, IOANA DEMETRESCU ${ }^{2,3}$, MIHAI LUPU $^{4}$ \\ ${ }^{1}$ National History Museum of Romania, Scientific Investigation Department, 12 Calea Victoriei, 030026, Bucharest, \\ Romania \\ ${ }^{2}$ University Politehnica of Bucharest, Faculty of Applied Chemistry and Materials Science, 1-7 Gh. Polizu Str., 011061, \\ Bucharest, Romania \\ ${ }^{3}$ Academy of Romanian Scientists, 54 Splaiul Independentei, 050094, Bucharest, Romania \\ ${ }^{4}$ National University of Arts, Faculty of Art History and Theory, Conservation and Restoration Department, 19 G-ral \\ Budisteanu Str., 010773, Bucharest, Romania
}

\begin{abstract}
This study's aim was to bring to light part of the hidden secrets of some important and valuable historical textiles beautifully adorned with precious metal threads, medieval gold brocaded velvet fragments and court vestments, which are preserved in the treasury collections of some of the most important monasteries and museums in our country. These precious metal thread textiles, includes historical and artistic information, as well as important scientific data regarding the materials and techniques used, their origin, provenience and dating, information that being revealed, have harmoniously blended and intertwined.
\end{abstract}

Keywords: Medieval velvet brocades, metal threads, Particle Induced X-ray Emission (PIXE), Rutherford Backscattering Spectrometry (RBS)

\section{Introduction}

The practice of decorating and adorning textiles and clothing with precious metal threads is an ancient tradition that had been practiced in various forms from the earliest times until the present days. A better knowledge of the metal thread nature and technology of production resulted from scientific investigations, can contribute to a better understanding and preservation of these historical textiles and to identification of the "fingerprint" of a particular culture that could make possible a documented textile to be read as a text from various perspectives. Metal threads being easily transportable materials of trading, it is possible that the ratios between their constituents, major, minor or trace elements, to may suggest their provenance and origin, or the manufacturing and distribution sites without indicating the sites of the weaving centers.

Apart from the need to describe, classify and document the materials used, the purpose of this research was to add clarifications on: (i) the qualitative, or possible quantitative differences between the metal threads used in the medieval brocaded velvets of Western or, possibly Oriental origin, from Moldavia and Wallachia, in order to determine the causes of their different preservation or degradation; (ii) identification of the morphological and technological differences resulting from the manufacturing process; (iii) the metal threads provenance, the possible influence of imports and reconstruction of the medieval trade routes.

Micro-PIXE combined with microscopy and RBS add important contribution and reveal new insights into the micro-chemical nature and complex structure of the very small and extremely thin golden threads for an accurate and complete characterization, allowing simultaneously determination of the chemical composition and distribution in the sample of the major, minor and trace elements by the use of micron-sized proton beams.

*email: balta_z_i@yahoo.com 
Table 1. Description of the selected textiles and samples, dating and areas of prelevation

\begin{tabular}{|c|c|c|c|}
\hline $\begin{array}{l}\text { Sample } \\
\text { Code }\end{array}$ & $\begin{array}{c}\text { Sample Description/ Prelevation } \\
\text { area }\end{array}$ & Selected Textiles/ Description & Textile Dating / Attribution \\
\hline C1 & $\begin{array}{l}\text { S+S undyed, embroidered inscription } \\
\text { of donation }\end{array}$ & \multirow{3}{*}{$\begin{array}{l}\text { Liturgical lectern cover - Gold brocaded } \\
\text { velvet fragment with inscription of } \\
\text { donation embroidered }\end{array}$} & \multirow{3}{*}{$\begin{array}{l}16^{\text {th }} \text { cent. (1502)?, Italy/ Putna } \\
\text { Monastery }\end{array}$} \\
\hline $\mathbf{C 2}$ & S+S yellow, floral decoration & & \\
\hline $\mathbf{C 3}$ & S+S undyed, velvet brocade & & \\
\hline $2 \mathrm{~m}$ & S+S yellow, velvet brocade & \multirow{2}{*}{$\begin{array}{l}\text { Tomb cover of Prince Stephan the Great - } \\
\text { Gold brocaded velvet with inscription of } \\
\text { donation embroidered }\end{array}$} & \multirow[t]{2}{*}{$\begin{array}{c}15^{\text {th }}-16^{\text {th }} \text { cent. (1474-1478)?, } \\
\text { Venice?/ Putna Monastery }\end{array}$} \\
\hline $3 \mathrm{~m}$ & $\mathrm{~S}+\mathrm{S}$ yellow, velvet brocade & & \\
\hline K1 & $\mathrm{S}+\mathrm{S}$ yellow, velvet brocade & $\begin{array}{l}\text { Tomb cover of Princess Maria Voichiţa - } \\
\text { Gold brocaded velvet ,drappi d'oro" with } \\
\text { inscription of donation embroidered }\end{array}$ & $\begin{array}{c}15^{\text {th }}-16^{\text {th }} \text { cent. (1513)?, Italy/ } \\
\text { Putna Monastery }\end{array}$ \\
\hline CB1 & S+S yellow, velvet brocade & \multirow{2}{*}{$\begin{array}{l}\text { Court vestment (Red caftan) - Gold } \\
\text { brocaded velvet }\end{array}$} & \multirow{2}{*}{$\begin{array}{l}15^{\text {th }} \text { cent., Venice?/ Bistriţa } \\
\text { Monastery, MNAR }\end{array}$} \\
\hline CB2 & S+S yellow, velvet brocade & & \\
\hline CC1 & S+S yellow, velvet brocade, collar & \multirow[b]{2}{*}{$\begin{array}{l}\text { Court vestment (Blue caftan) - Gold } \\
\text { brocaded velvet }\end{array}$} & \multirow[b]{2}{*}{$\begin{array}{c}16^{\text {th }} \text { cent., Venice?/ Bistriţa } \\
\text { Monastery, MNAR }\end{array}$} \\
\hline $\mathrm{CC2}$ & $\begin{array}{l}\text { S+S yellow, velvet brocade, right } \\
\text { sleeve }\end{array}$ & & \\
\hline L1 & $\mathrm{S}+\mathrm{S}$ yellow, velvet brocade & $\begin{array}{c}\text { Brocaded velvet fragment - Gold } \\
\text { brocaded velvet }\end{array}$ & $\begin{array}{c}16^{\text {th }} \text { cent., Venice/ Putna } \\
\text { Monastery }\end{array}$ \\
\hline 4d & $\mathrm{S}+\mathrm{S}$ yellow, velvet brocade & $\begin{array}{c}\text { Court vestment reconstituted from a } \\
\text { phelonion }\end{array}$ & $\begin{array}{c}15^{\text {th }} \text { cent., Venice?/ Cozia } \\
\text { Monastery, MNAR }\end{array}$ \\
\hline 5d & $\mathrm{S}+\mathrm{S}$ yellow, velvet brocade & $\begin{array}{l}\text { Court vestment reconstituted from a tomb } \\
\text { cover }\end{array}$ & $\begin{array}{c}15^{\text {th }}-16^{\text {th }} \text { cent.?, Italy/ Bistriţa } \\
\text { Monastery, MNAR }\end{array}$ \\
\hline
\end{tabular}

Symbols: W - metal wire; $\mathrm{S}+\mathrm{S}$ - metal strip wrapped around a silk yarn

\section{Materials and methods}

Samples were selected from three different categories of medieval velvet brocades with

known or unknown provenience and consistent dating as appear in the historical literature: (i) velvet brocade textiles with an embroidered inscription of donation, usually used as tomb covers or liturgical textiles; (ii) velvet brocade fragments, typological and stylistically similar, but with no inscription of donation, for liturgical purposes during the religious service; and (iii) velvet brocade gold cloths worn as court garments and vestments of Italian or Oriental influence by the Moldavian and Wallachian princes, princesses or boyars (ceremony costumes, caftans, granatza etc.).

Brocaded velvets were luxurious and sumptuous materials of silk velvet richly decorated with gold or silver threads that were imported and produced abroad in the Italian workshops from Venice, Florence or Genoa, or in the Ottoman Empire workshops, as mentioned in the historical literature [1]. They were sometimes donated to churches and monasteries after being worn. With a simple cut, those clothes could be dismantled, the resulting textile fragments being used during the religious services as temple veils, covers for lecterns or as tomb covers [1]. Information on the selected textiles from which the metal threads were prelevated is presented in Table 1.

Two types of metal threads have been investigated in the present study: wires with no yarn core and strips wound around a yellow or an undyed silk yarn.

Preliminary examinations by optical microscopy, in reflected and polarized light, at

different magnifications, were performed with a Nikon Eclipse LV100D optical microscope

equipped with a D90 digital camera, a Camera Control Pro 2.0 imaging software and a NIS Elements-BR3.0 image analysis software. Further microscopy examinations have been done at an accelerating voltage of $20 \mathrm{KV}$ and $10-50 \mu \mathrm{A}$ intensity, with a scanning electron microscope (SEM) LEO 435VP mounted on a Roentec M1 EDX spectrometer, in order to determine the metal threads technological and morphological characteristics.

The ion beam analysis (IBA) were carried out at the $5 \mathrm{MV}$ Van de Graaff particle accelerator of the Institute of Nuclear Research of the MTA ATOMKI (Debrecen, Hungary) within the European project IPERION-CH and at the Ion Beam Analysis Laboratory 2MV Tandetron accelerator (University of Surrey's Ion Beam Centre, UK) within the European project SPIRIT. Samples were analyzed in 
vacuum by micro-PIXE using a proton beam of $2.5-3 \mathrm{MeV}$ energy and $100-500$ pA intensity, followed by RBS measurements. PIXE elemental maps were recorded in two different modes: scanning of the full sample and of two selected homogeneous areas of $500 \mu \mathrm{m}^{2}, 750 \mu \mathrm{m}^{2}$ or $1 \mathrm{~mm}$ scan size, depending of the sample, in order to reveal the constituent elements distributions in the sample and for technological features identification. The raw data was analyzed by deconvolution of the PIXE spectra with the GUPIX code [2]. RBS analysis on metal threads was performed by using an ORTECtype surface barrier silicon detector ("ULTRA" Ion-Implanted, $50 \mathrm{~mm}^{2}$ sensitive area and $25 \mathrm{keV}$ system energy resolution). The detector was placed at a scattering angle of $165^{\circ}$ at Cornell geometry $[3,4]$. The scan size was set to $500 \times 500 \mu \mathrm{m}^{2}$. RBS spectra were evaluated with the SimNRA computer code version 6.06 [5].

\section{Results and discussions}

By optical and SEM microscopy observations, two different categories of strips - cut and flattened - were identified, by taking in consideration the metal threads morphological and technological characteristics. According to the written sources [6], the cut or so-called "beaten and cut" strips are early times threads dated from the $13^{\text {th }}$ century onwards, uneven in size and quality and of variable thickness, obtained by cutting a gilt silver sheet. The flattened or "cast, drawn and rolled" strips, dated from the $14^{\text {th }}$ century onwards, were obtained from silver roads that were cast, gilded and drawn into wires which were then flattened between two metal rollers and wrapped around a yellow or white undyed silk for gilt or silver threads [7,8]. They have even width all along their length and show parallel pronounced, deep lines on their surface resulted from the wire drawing process. In the Figure 1 and Figure 2 could be seen the characteristics of the two categories of metal threads identified, as observed by optical and SEM microscopy, for samples L1 and 4d - as flatten "cast, drawn and rolled" strips, and for samples $\mathrm{CC} 2,2 \mathrm{~m}$ and $5 \mathrm{~d}$ - as "beaten and cut" strips.
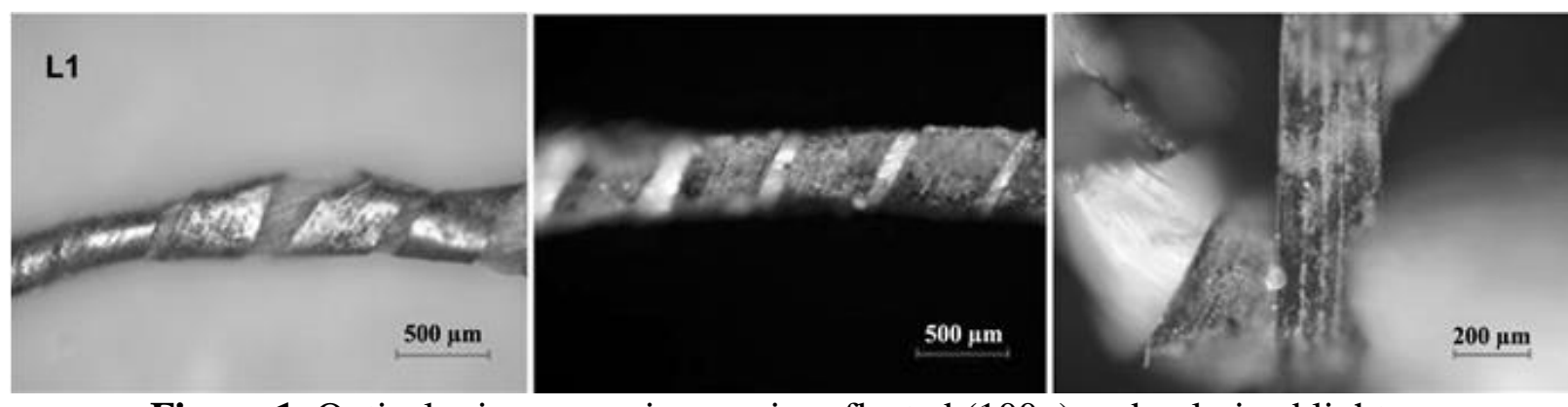

Figure 1. Optical microscopy images in reflected (100x) and polarized light (100x and 200x) of the sample L1 - gilded silver strip wrapped around a silk yellow yarn
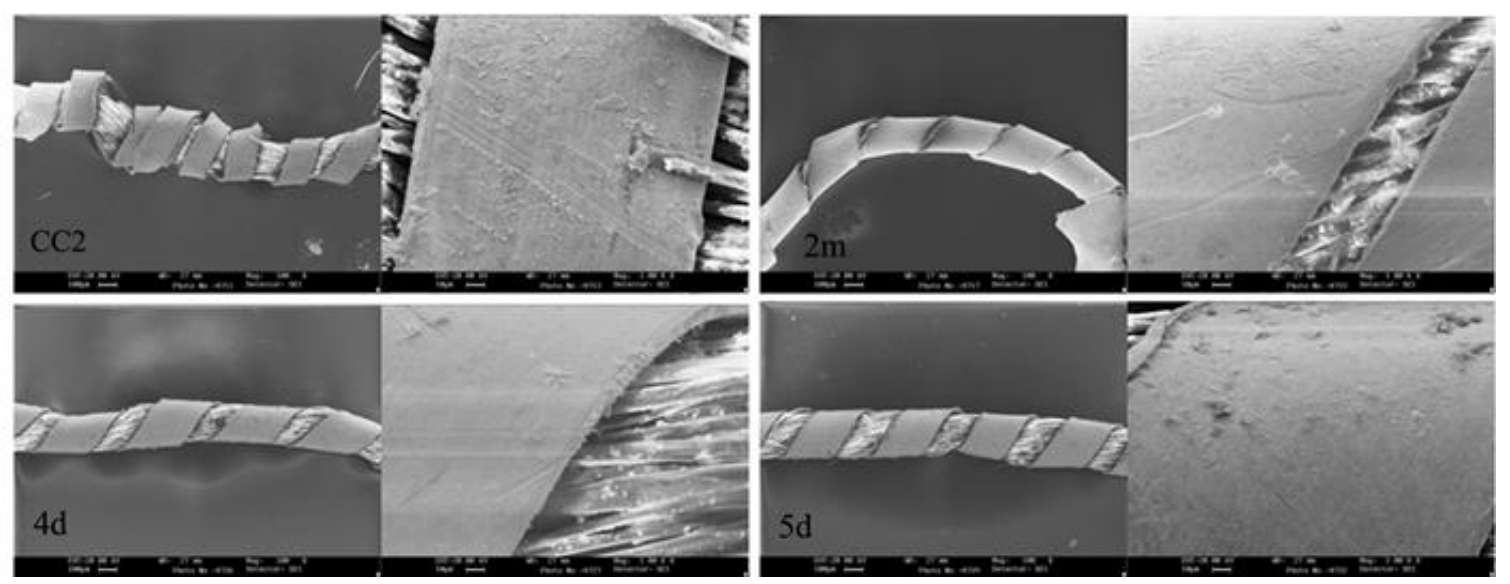

Figure 2. SEM micrographs (100x and 1000x) of samples CC2, 2m, 4d and 5d 
By micro-PIXE analysis, in all the studied samples (wires and strips) elements identified were: silver as a major element, then gold, copper, lead, calcium, iron and bismuth, as minor or in trace elements that gave important historical clues regarding the method of production, the provenience and origin of the metal threads, as well as the gilding technologies that were employed. In the Table 2 are shown the chemical compositions of the metal threads resulting by PIXE.

Table 2. Constituent elements concentrations (wt.\%) in the samples resulted by PIXE

\begin{tabular}{|c|c|c|c|c|c|c|c|c|c|c|c|}
\hline \multirow{2}{*}{ Sample Code } & \multicolumn{9}{|c|}{ Elemental composition (wt.\%) } \\
& $\mathbf{A g}$ & $\mathbf{A u}$ & $\mathbf{C u}$ & $\mathbf{P b}$ & $\mathbf{B i}$ & $\mathbf{F e}$ & $\mathbf{C a}$ & $\mathbf{S}$ & $\mathbf{C l}$ & $\mathbf{S i}$ & Na \\
\cline { 2 - 12 } & & & & & & & & & \\
\hline C1 sel1 & 85.9 & 5.99 & 3.14 & 0.14 & & 0.07 & 0.29 & 2.65 & 1.05 & & \\
\hline C1 sel2 & 88.00 & 5.66 & 3.78 & 0.14 & & 0.09 & 0.44 & & 1.47 & & \\
\hline C2 sel1 & 85.92 & 5.38 & 3.52 & 0.13 & & 0.61 & & 1.18 & 1.38 & 0.32 & \\
\hline C2 sel2 & 85.62 & 9.00 & 1.99 & 0.10 & & 0.09 & 0.46 & & 1.49 & 0.40 & 0.39 \\
\hline C3 sel1 & 91.86 & 2.24 & 3.73 & 0.16 & & 0.05 & 0.36 & & 0.84 & 0.33 & \\
\hline C3 sel2 & 91.78 & 2.23 & 4.41 & 0.15 & & 0.09 & & & & & \\
\hline 2m_sel1 & 89.4 & 2.40 & 4.40 & 0.31 & & 1.08 & 0.30 & & 0.69 & & \\
\hline 2m_sel2 & 91.43 & 2.76 & 3.40 & 0.34 & & 0.04 & & & 1.67 & & \\
\hline 3m_sel1 & 87.5 & 5.57 & 3.30 & 0.01 & 0.05 & 0.12 & 0.58 & 0.90 & 0.50 & 0.17 & 0.5 \\
\hline 3m_sel2 & 92.34 & 3.79 & 2.61 & 0.08 & 0.04 & 0.07 & & & 0.69 & & \\
\hline K1 sel1 & 87.58 & 5.78 & 3.6 & 0.18 & 0.14 & 0.06 & 0.51 & & 1.24 & 0.46 & 0.46 \\
\hline K1 sel2 & 89.21 & 4.61 & 3.38 & 0.19 & 0.12 & 0.05 & 0.41 & & 1.46 & & \\
\hline CB1_sel1 & 88.27 & 4.4 & 4.65 & 0.13 & & 0.07 & 0.29 & 0.27 & 0.84 & 0.18 & 0.53 \\
\hline CB1_sel2 & 87.02 & 3.26 & 7.03 & 0.18 & & 0.06 & 0.28 & 0.27 & 0.82 & 0.18 & 0.52 \\
\hline CB2_sel1 & 88.77 & 2.65 & 6.96 & 0.36 & & 0.04 & & 0.3 & 0.45 & 0.12 & \\
\hline CB2_sel2 & 87.39 & 3.45 & 6.19 & 0.35 & & 0.06 & & 0.28 & 0.72 & 0.2 & 0.81 \\
\hline CC1_sel1 & 87.91 & 1.23 & 8.93 & 0.12 & & 0.05 & & & 0.99 & 0.26 & \\
\hline CC1_sel2 & 85.88 & 3.25 & 9.19 & 0.11 & & 0.06 & & & 0.75 & & \\
\hline CC2_sel1 & 92.71 & 2.15 & 0.45 & 0.04 & & 0.05 & & 2.09 & 1.63 & 0.26 & \\
\hline CC2_sel2 & 92.27 & 2.15 & 0.49 & 0.03 & & 0.05 & & 3.55 & 0.8 & 0.21 & 0.25 \\
\hline L1_sel1 & 95.74 & 1.41 & 0.48 & 0.03 & 0.03 & 0.06 & 0.26 & 0.36 & 0.77 & 0.38 & 0.2 \\
\hline L1_sel2 & 96.24 & 1.22 & 0.47 & 0.03 & 0.03 & 0.05 & 0.1 & 0.4 & 0.84 & 0.31 & 0.14 \\
\hline L1_sel3Au & 71.39 & 8.64 & 0.6 & 0.02 & & 0.25 & 7.74 & & 1.94 & 1.57 & 4.32 \\
\hline 4d_sel1 & 85.68 & 1.80 & 5.72 & 0.10 & & 0.05 & & 2.20 & 3.46 & 0.40 & \\
\hline 4d_sel2 & 80.63 & 2.00 & 7.58 & 0.09 & & 0.18 & 3.09 & 1.32 & 2.13 & 1.29 & \\
\hline 5d_sel1 & 83.99 & 3.60 & 2.78 & & 0.06 & 0.07 & 0.81 & 1.59 & 0.34 & 0.75 & \\
\hline 5d_sel2 & 85.97 & & & & 0.08 & 0.05 & & 1.20 & 0.19 & 0.83 & \\
\hline
\end{tabular}

Because of the restriction imposed by the GUPIX code in evaluating the PIXE elemental compositions results in which it was assumed that the gold layer contains only $100 \%$ gold, no mercury was possible to be determined in the extremely thin gold layer. However, its presence was detected in the PIXE elemental maps showing the spatial distribution of the elements present in the samples. In the Figure 3 are presented the PIXE elemental maps resulted for samples $2 \mathrm{~m}$ and $3 \mathrm{~m}$.

From the PIXE data obtained resulted that three different types of materials were used for production of the metal threads in the medieval velvet brocades from Moldavia and Wallachia: gilded high purity silver and gilded silver-copper alloys with significant variations in copper or gold.

Gilded silver with gold in minor quantities (1 - 2\% wt.) and copper in traces (less than $0.5 \%$ wt.) was detected in the sample L1 from the Venetian velvet brocaded fragment (Putna Monastery) and CC2 from the right sleeve brocaded velvet (Blue caftan, Bistriţa Monastery/ MNAR). The high concentration of silver detected in these metal strips indicated a pure silver refined through cupellation and gilded, possibly with fine gold purified by cementation.

Silver alloy with copper of about $2-4 \%$ wt. and gold in major quantities (3 - 6\% wt.) was determined in the samples $2 \mathrm{~m}, 3 \mathrm{~m}, \mathrm{~K} 1$ and $\mathrm{C} 3$, from the brocaded velvets of the Putna Monastery, and in sample $5 \mathrm{~d}$ from the court vestment reconstituted from a tomb cover (Bistriţa Monastery/ MNAR). 

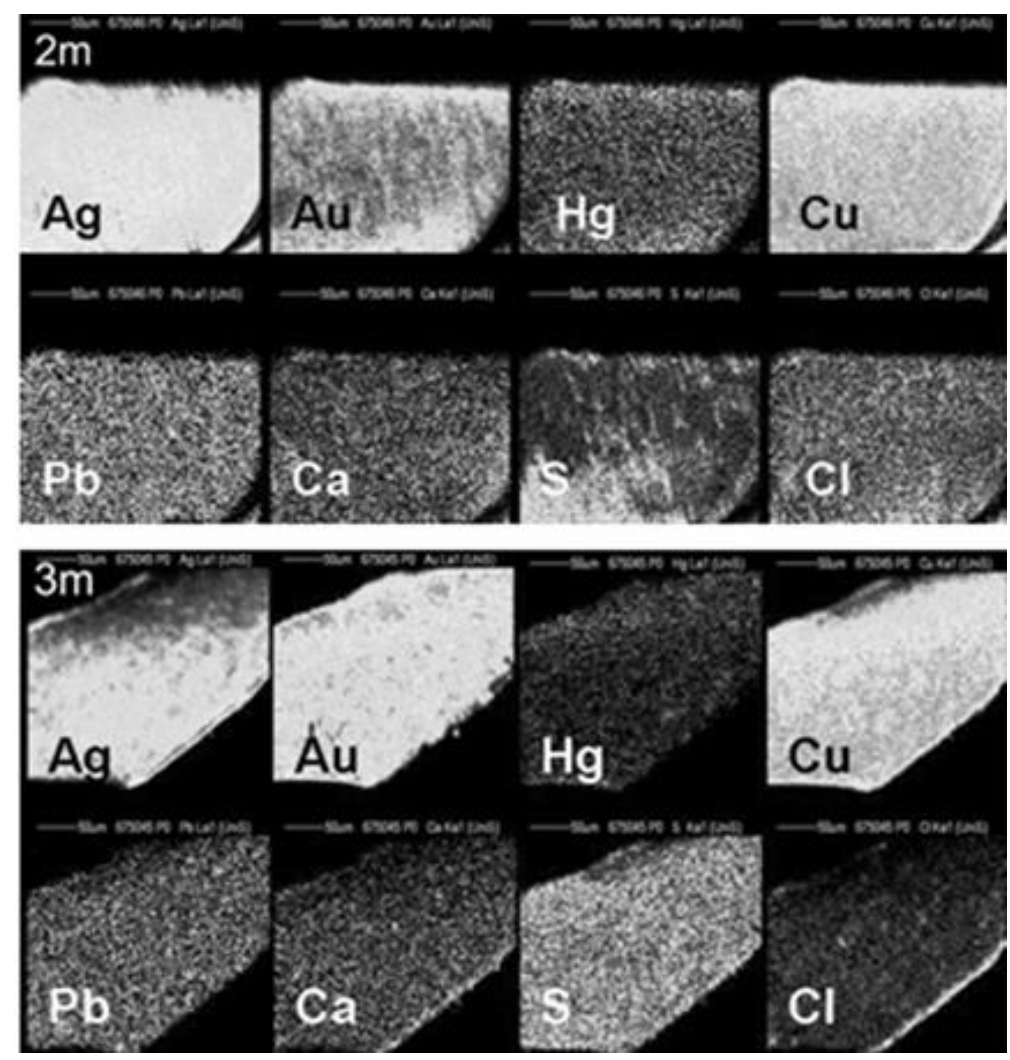

Figure 3. PIXE elemental distribution maps as resulted for samples $2 \mathrm{~m}$ and $3 \mathrm{~m}$

Silver alloy with copper of about $3 \%$ wt. and gold in major quantities (6-9\% wt.) was determined in the samples $\mathrm{C} 1$ and $\mathrm{C} 2$ from the embroidered inscription and floral decoration from the liturgical lectern cover (Putna Monastery). Also, silver alloy but with $6-9 \%$ wt. copper and gold of about 3\% wt. was detected in the samples CB1, CB2 (Red caftan, Bistriţa Monastery/ MNAR), CC1 ((Blue caftan's collar, Bistriţa Monastery/ MNAR) and 4d (Court vestment reconstituted from a phelonion, Cozia Monastery/ MNAR).

It has been suggested by some scientists that there is a connection between the metal thread provenance and the variations in copper concentration in the silver alloy, the silver to copper ratio in the European gilded silver threads being lower than in the more pure gilded silver threads of Oriental or Byzantine origin [7]. The presence or absence of copper may be significant in indicating the purity of the silver used, in the fine pure silver the copper concentration being less than $2 \% \mathrm{wt}$., according to the literature [9]. Copper content in the metal threads from all the brocaded velvets studied, indicated a triple Italian provenance, possibly originating from Venice, Florence or Genoa [9]. The micro-PIXE analysis results revealed a different provenance of the metal threads in the brocaded velvets from Moldavia (with copper concentrations of less than $0.5 \%$ wt. for the Venetian velvets, and about $2-4 \%$ wt. for those possibly Florentine velvets) compared to those from Wallachia (with copper concentrations of between 6 - 9\% wt., possibly Genoese velvets). In some Romanian historical sources is mentioned that the most beautiful Florentine gold brocaded velvets are kept at the Monastery of Putna as princely tomb covers or temple veils [4]. Furthermore, C. Nicolescu mentions that the fragments of brocaded velvets discovered by Al. Odobescu in the treasury collections of the monasteries of Bistriţa and Cozia, were named "Genoese carpets", by the historians Gr. Tocilescu and Sp. Ceganeanu [1].

PIXE results revealing a different provenance of the metal threads from the velvet brocades from Moldavia compared to those from Wallachia, could be explained by the existence of the two major different commercial routes that connected the two Romanian countries with the Western and Oriental 
worlds. The trading partners of Wallachia in the $14^{\text {th }}$ and $15^{\text {th }}$ centuries were Transylvania through Sibiu and Brasov, Poland through Lvov, and the Genoese and through them the Byzantine Empire. On the Moldavian territory, the other major trans-European road, which supplied from the Near Eastern world by the Black Sea, was linking Cetatea Alba and Chilia, the main Moldavian ports during the reign of Prince Stephen the Great, of Lvov, from where through Poland, it continued either to Prague, to Silesia, or to Gdansk, on the shore of the Baltic Sea [10].

In complementarity to PIXE, the RBS measurements contributed to improve the knowledge on the metal threads technologies of production, by providing information on their micro-chemical structure and the thickness of the gilding coating [11]. By evaluating the RBS spectra, it was observed that gold is separated from the bulk silver by an intermediate layer resulting from the atomic diffusion of the silver into the gold layer, which led to the conclusion that the gold may have been applied on silver either by thermal diffusion ("diffusion bonding"), or by hot mercury amalgamation (,fire gilding”). Hoke and Petrascheck-Heim mentions that mercury was used in the silver gilding amalgamation process to increase the diffusion of silver and gold between the two layers [7]. In the Figure 4 is shown the RBS spectra resulted for the sample $2 \mathrm{~m}$.

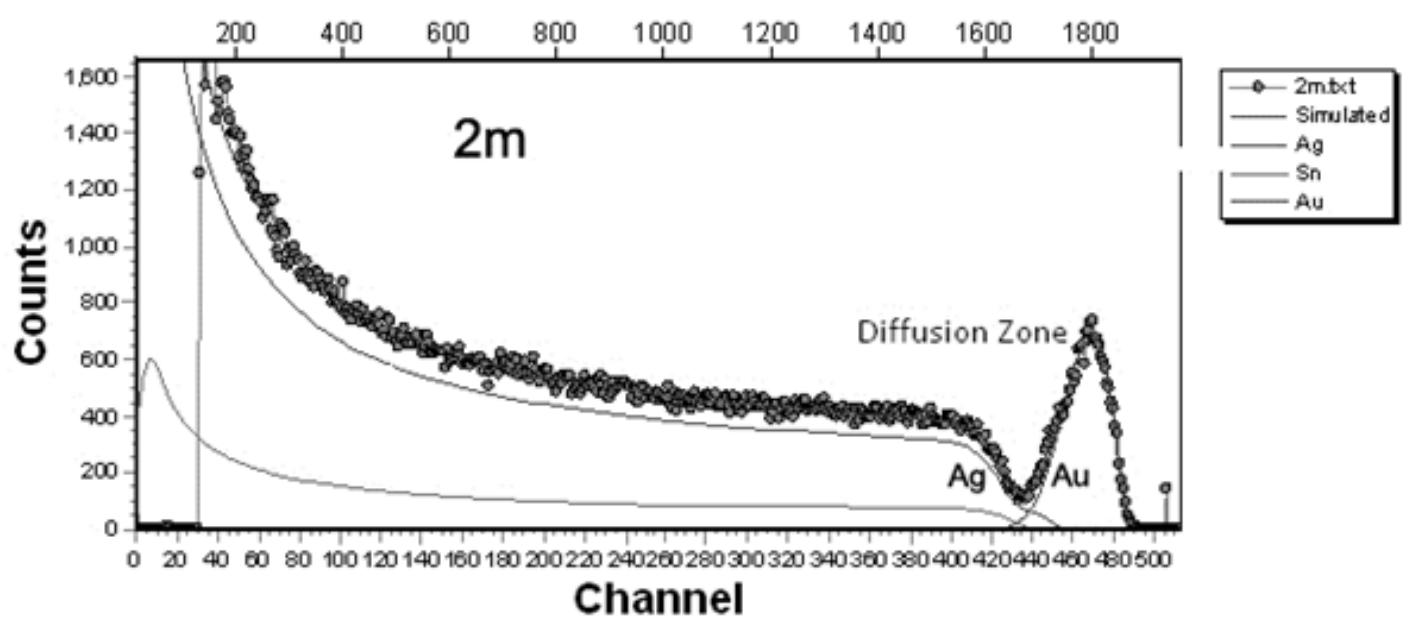

Figure 4. RBS spectra resulted for sample $2 \mathrm{~m}$

By RBS analysis was revealed that the structure of the metal threads consists of four layers: the silver bulk substrate, the atomic diffusion layer of silver into the gold, gold layer and an organic protective layer of a material determined by micro-ATR/ FT-IR as wax or gum arabic/ acacia or gelatin mostly for the metal strips from the brocaded velvets which is accordance with the written sources $[12,13]$.

\section{Conclusions}

The main objective of our study was to reveal new insights into the micro-chemical nature of the very small and thin, possibly multilayered metal threads used for manufacturing the luxurious medieval gold brocaded velvets and to bring new supplementary and more in-depth information on their complex structure by using the advanced ion beam analysis techniques, PIXE and RBS, for authentication, attribution and provenience purposes. The new and interesting information obtained by scientific analysis can complement and correct the historical and artistic studies and could considerably contribute to the understanding and knowledge of these precious metal thread textiles, and as well to the extending of their life by choosing and applying appropriate restoration and conservation treatments. 
Acknowledgements: The authors are very grateful to Dr. G. Grime from the University of Surrey's Ion Beam Centre (UK) and to the researchers from the MTA ATOMKI (Debrecen, Hungary) for all their kind scientific support and collaboration during the ion beam measurements within the SPIRIT and CHARISMA projects.

\section{References}

1. NICOLESCU, C., Costumul de Curte in Tarile Romane (Sec. XIV - XVIII), Intreprinderea Poligrafica Arta Grafica, Bucharest, 1970

2. CAMPBELL, J.L., BOYD, N.I., GRASSI, N., BONNICK, P., MAXWELL, J.A., The Guelph PIXE software package IV, Nucl. Instr. Meth. B, 268, 2010, p. 3356-3363

3. SIMON, A., HUSZANK, R., NOVAK, M., PINTYE, Z., Investigation of hydrogen depletion of organic materials upon ion beam irradiation by simultaneous micro-RBS and micro-ERDA techniques, Nucl. Instr. Meth. B, 268, 2010, p. 2197-2201

4. HUSZANK, R., SIMON, A., SZILAGYI, E., KERESZTESSY, K., KOVACS, I., Micro-ERDA, micro-RBS and micro-PIXE techniques in the investigation of fish otoliths, Nucl. Instr. Meth. B, 267, 2009, p. 2132-2135

5. MAYER, M., SIMNRA user's guide, Tech. Rep. IPP 9/113, Max-Planck-Institut fur Plasmaphysik, Garching, 1997

6. BARKER, A.D., Gold lace and embroidery: A brief survey of the manufacture and use of precious metal wires and threads for embroidery and weaving, Northern Soc. Costume Text., 1980, p. 1-14

7. HOKE, E., PETRASCHECK-HEIM, I., Microprobe Analysis of Gilded Silver Threads from Medieval Textiles, Studies in Conservation, 22, 1977, p. 49-62

8. DARRAH, J.A., Metal Threads and Filaments, Recent advances in the conservation and analysis of artifacts: jubilee conservation conference papers, Summer Schools Press University of London Institute of Archaeology, Ed. J. Black, London, 1987, p. 211-221

9. INDICTOR, N., KOESTLER, R.J., BLAIR, C., WARDWELL, A.E., The Evaluation of Metal Wrappings from Medieval Textiles Using Scanning Electron Microscopy-Energy Dispersive X-Ray Spectrometry, Textile History, 19, no. 1, 1988, p. 3-19

10. GIURESCU, D.C., Tara Romaneasca in secolele XIV - XV, Ed. Stiintifica, Bucharest, 1973, p. 150-192

11. BALTA, Z.I., CSEDREKI, L., FURU, E., CRETU, I., HUSZANK, R., LUPU, M., TOROK, Z., KERTESZ, Z., SZIKSZAI, Z., Nucl. Instr. Meth. B, 348, 2015, p. 285-290

12. BALTA, Z.I., DEMETRESCU, I., CRETU, I., LUPU, M., U.P.B. Sci. Bull. Series B, 79, no. 2, 2017, p. 25-36

13. MOLA, L., The silk industry of Renaissance Venice, The Johns Hopkins University Press, Baltimore, 2000, p. 138-140

Manuscript received: 20.11 .2019 